\title{
Adsorption and Inhibitive Properties of Leaf Extract of Newbouldia leavis as a Green Inhibitor for Aluminium Alloy in $\mathrm{H}_{2} \mathrm{SO}_{4}$
}

\author{
Lebe A. Nnanna ${ }^{1, *}$, Onyinyechi C. Nwadiuko ${ }^{1}$, Nneka D. Ekekwe ${ }^{2}$, Chibueze F. Ukpabi ${ }^{2}$, \\ Solomon C. Udensi ${ }^{3}$, Kelechukwu B. Okeoma ${ }^{3}$, Beniah N. Onwuagba ${ }^{3}$, Ihebrodike M. Mejeha ${ }^{3}$ \\ ${ }^{1}$ Department of Physics/Electronics, Abia State Polytechnic, P. M. B. 7166, Aba, Nigeria \\ ${ }^{2}$ Department of Chemistry, Abia State Polytechnic, P. M. B. 7166, Aba, Nigeria \\ ${ }^{3}$ Department of Physics, Federal University of Technology, P. M. B. 1526, Owerri, Nigeria
}

\begin{abstract}
The corrosion inhibition of Al and its alloys is the subject of tremendous technological importance due to the increased industrial applications of these materials. This study reports the corrosion inhibition of AA8011 aluminium alloy in acidic solutions using Newbouldia leavis leaf extract by way of gravimetric measurements. It was shown that the presence of Newbouldia leavis leaf extract inhibited the corrosion of aluminium in the test solutions and the inhibition efficiency depended on the concentration of the plant extract as well as on the time of exposure of the aluminium samples in $\mathrm{H}_{2} \mathrm{SO}_{4}$ solutions containing the extract. The experimental data complied to the Langmuir adsorption isotherm and the value and sign of the Gibb's free energy of adsorption obtained suggested that inhibitor molecules have been spontaneously adsorbed onto the aluminium surface through a physical adsorption mechanism.
\end{abstract}

Keywords Corrosion Inhibition, Aluminium, Adsorption Mechanism, Newbouldia leavis, Free Energy of Adsorption

\section{Introduction}

Aluminium and its alloys have proved to be strategically important materials and have extensive use in many industries. They are used in the automotive, aviation and aerospace industries, in the making of household appliances, in ship building and military hardware[1-3]. Their usefulness is derived from their very good physical and mechanical properties such as their high strength-to-weight ratio, recyclability, good machining properties, as well as their outstanding resistance to corrosion. The corrosion resistance of aluminium and its alloys is attributable to the formation of a stable protective thin film of aluminium oxide when first produced and exposed to the atmosphere. Nevertheless, when exposed to an aggressive environment (acidic or alkaline), they are prone to corrosion and degradation. The protective oxide film is of amphoteric character and easily dissolved in strong acidic and alkaline media[4-5] leading to a sequence electrochemical reaction. Corrosion is accompanied by many conjugate cathodic processes in which hydrogen gas evolution is often predominant in strong acid and alkaline solutions[6-8]. Corrosion control of aluminium and

* Corresponding author:

lebennanna@yahoo.com (Lebe A. Nnanna)

Published online at http://journal.sapub.org/materials

Copyright (C) 2011 Scientific \& Academic Publishing. All Rights Reserved its alloys can be enhanced by the addition of some inorganic substances to the corrodent. The substances include phos-phates, chromates, dichromates, silicates, bromates, arsenates, tungstates, molybdates, chlorides and their likes[9-12]. These inorganic inhibitors exhibit toxic effects and are therefore not environmentally friendly. As a result, there has been a search for corrosion inhibitors which are not harmful to the environment.

Fortuitously, it has been found that certain organic substances containing polar functions with nitrogen, sulphur and/or oxygen atoms in the conjugated system have been reported to exhibit good inhibiting properties of steel in acidic and alkaline environments[10,13-20]. Incidentally, parallel studies of the inhibiting effects of organic compounds, both synthetic and naturally occurring, have been conducted on aluminium and its alloys in aggressive acidic and alkaline environments[3,4,16,18,21-31]. The results of all these studies suggest that the inhibitory behaviour of the organic compounds subsists in some chemical species or molecules in the inhibiting substances forming a protective layer between the metal surface and the corrodent. The adsorbate layer formed isolates the metal surface from the corrodent thereby reducing the corrosion rate of the metal surface. These studies have also yielded some insights into the adsorption mechanisms responsible for the inhibitive properties of organic inhibitors. It has been recognized that the use of organic inhibitors, particularly the naturally oc- 
curring organic inhibitors of plant origin, are viable and highly beneficial since they are essentially non-toxic, environmentally benign, readily available, renewable and inexpensive[10,12,19,20,24,32,33].

The inhibiting effect of Newbouldia leavis plant extract on aluminium alloy (AA8011) in $0.5 \mathrm{M} \mathrm{H}_{2} \mathrm{SO}_{4}$ was investigated. This study has dual purposes, first to establish the effectiveness of the plant extracts as corrosion inhibitors and secondly to attempt deduction of the inhibition mechanisms through adsorption isotherms. This work is done at high concentration limit to determine optimum concentration of the extract. The equation for corrosion rate is given by

$$
C=k \Delta W / \rho A t
$$

Where $\mathrm{K}=$ Rate constant equal 534 mpy; mpy means mils per year

$\mathrm{W}=$ Weight loss in $\mathrm{mg}$

$\rho=$ Density of material in $\mathrm{g} / \mathrm{cm}^{3}$

$\mathrm{T}=$ Exposure time in hours

$\mathrm{A}=$ Exposed area of coupon in ${ }^{2}$

noting that $1 \mathrm{in}^{2}=6.5416 \mathrm{~cm}^{2}$.

\section{Materials and Methods}

Aluminium alloy AA8011 specimens having weight percentage composition as follows; $\mathrm{Si}-0.240 \%$, $\mathrm{Fe}-0.241 \%$, $\mathrm{Cu}-0.035 \%$, Mn- $0.102 \%$, Ti- $0.019 \%$, Pb- $0.014 \%$, Zn$0.043 \%$ and the remainder being $\mathrm{Al}$ were used. The specimens were of dimensions $2 \mathrm{~cm} \times 2 \mathrm{~cm}$ and thickness 1.32 $\mathrm{mm}$. The alloy specimen were polished mechanically using $\mathrm{SiC}$ emery papers of grade nos 220,400 and 600 , washed thoroughly with distilled water and degreased with ethanol and acetone. The specimens were then air dried before being immersed in the acid solution. The blank corrodent was 0.5 $\mathrm{M} \mathrm{H}_{2} \mathrm{SO}_{4}$ solution. Stock solutions of the plant extract were prepared by boiling weighed amounts of the dried and ground plant material for 3 hours in the $0.5 \mathrm{M} \mathrm{H}_{2} \mathrm{SO}_{4}$. The solutions were cooled and then filtered and stored. From the respective stock solutions, inhibitor test solutions were prepared in the concentration range of $0.1-0.4 \mathrm{~g} / \mathrm{L}$ using excess acid as solvent at room temperature and $60^{\circ} \mathrm{C}$ using water bath.

\section{Gravimetric experiment}

The cleaned and dried specimens were weighed before immersion into the respective test solutions of $0.5 \mathrm{M} \mathrm{H}_{2} \mathrm{SO}_{4}$ using JA $1003 \mathrm{~A}$ electronic weighing balance with the accuracy of 0.005 . Tests were conducted with different concentrations of inhibitor. At the end of the tests, the specimens were carefully washed in absolute ethanol having used nitric acid to quench further corrosion from taking place, and then reweighed. Triplicate experiments were performed in each case and the mean values reported.

\section{Results and Discussion}

\subsection{Gravimetric Technique and Corrosion Rates}

The corrosion rates of the aluminium in $0.5 \mathrm{M} \mathrm{H}_{2} \mathrm{SO}_{4}$ in the absence and presence of Newbouldia leavis leaf extract were determined at room temperature (303K). Figure 1 shows the time variation of corrosion rates of the aluminium in $0.5 \mathrm{M} \mathrm{H}_{2} \mathrm{SO}_{4}$ with and without the Newbouldia leavis leaf extract, while Figure 2 shows the variation of the corrosion rates of the aluminium in $0.5 \mathrm{M} \mathrm{H}_{2} \mathrm{SO}_{4}$ with inhibitor concentration.

Figure 4 illustrates the variation of the corrosion rates of the aluminium in $0.5 \mathrm{M} \mathrm{H}_{2} \mathrm{SO}_{4}$ with inhibitor concentration for an exposure time of 8 hours. Figures 3 and 4 show clearly that the leaf extract retards the corrosion rate of the aluminium in the test solutions. Moreover, it can be seen from Figure 4 that the corrosion rate decreases with increase in the concentration of the inhibitor. The inhibition efficiency of the Newbouldia leavis leaf extract on the corrosion of the aluminium in $0.5 \mathrm{M} \mathrm{H}_{2} \mathrm{SO}_{4}$ containing different concentrations of the leaf extract was computed by using the relation[ 4 , $10,19]$.

$$
\mathrm{I} \%=\left(1-\rho_{\text {inh }} / \rho_{\text {blank }}\right)
$$

where I\% represents the inhibition efficiency expressed in percentage, $\rho_{\text {inh }}$ is the corrosion rate in the presence of the inhibitor while $\rho_{\text {blank }}$ is the corrosion rate in the absence of inhibitor. Optimum value of $92 \%$ at $0.4 \mathrm{~g} / \mathrm{L}$ concentration of Newbouldia leavis extract was obtained as shown in Figure 4.

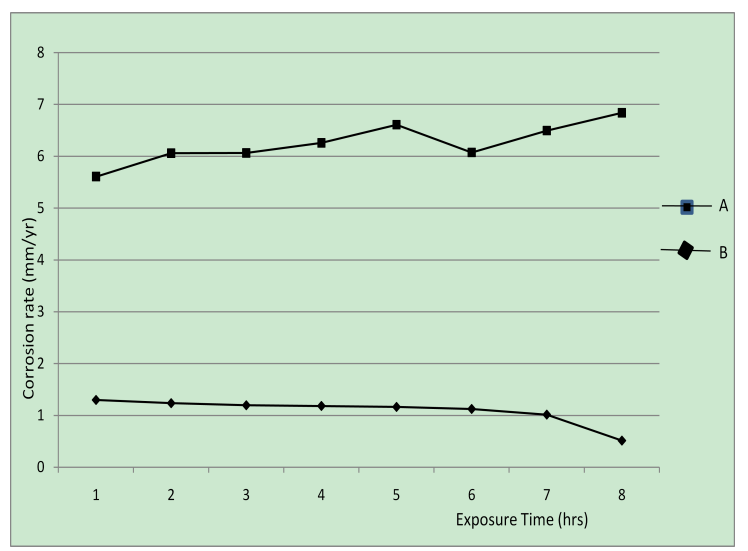

Figure 1. Time variation of the corrosion rates of aluminium in $0.5 \mathrm{M}$ $\mathrm{H}_{2} \mathrm{SO}_{4}$. (A) without inhibitor (B) with Newbouldia leavis leaf extract of concentration $0.4 \mathrm{~g} / \mathrm{L}$

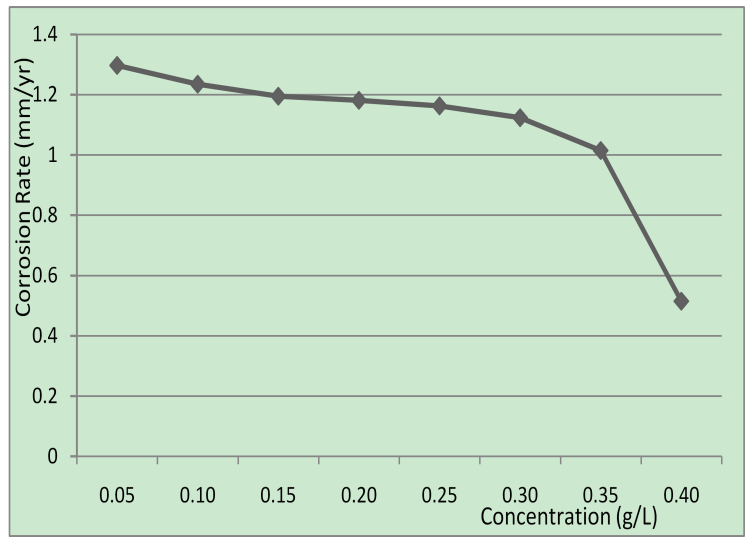

Figure 2. Variation of corrosion rate of aluminium in $0.5 \mathrm{M} \mathrm{H}_{2} \mathrm{SO}_{4}$ with different concentrations of Newbouldia leavis extract 


\subsection{Inhibition efficiency}

Clearly, the inhibition efficiency of Newbouldia leavis leaf extract increases with exposure time for the inhibitor concentration considered. This result is consistent with the findings of[31] who showed that the inhibition efficiency of Euphorbia hirta in the corrosion of the aluminium alloys AA3003 in $0.5 \mathrm{M} \mathrm{HCl}$ increases with exposure time. As shown in Figure 4, the inhibition efficiency increases with increase in inhibitor concentration, tending to saturate at higher values of inhibitor concentration. This indicates that the effectiveness of the Newbouldia leavis leaf extract in retarding the corrosion rate of aluminium in the test solutions does not improve indefinitely with increase in inhibitor concentration. A point is reached at which an increase in the inhibitor concentration produces only a very small increase in inhibition efficiency. A similar conclusion has been reached by $[12,34]$ who studied the inhibitive effect of thiosemicarbozides on the corrosion of steel in phosphoric acid and the inhibitive effect of Solanum melongena L. Leaf extract on the corrosion of aluminium in tetraoxosulphate (VI) acid respectively.

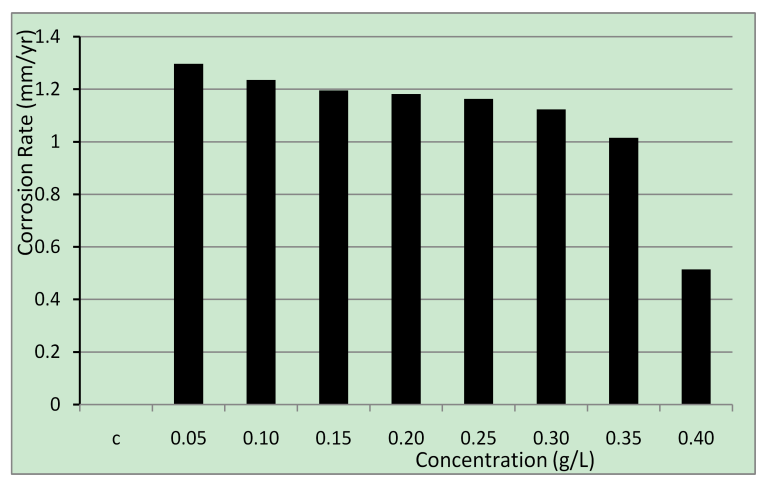

Figure 3. Variation of corrosion rate of aluminium in $0.5 \mathrm{M} \mathrm{H}_{2} \mathrm{SO}_{4}$ with different concentrations of Newbouldia leavis leaf extract

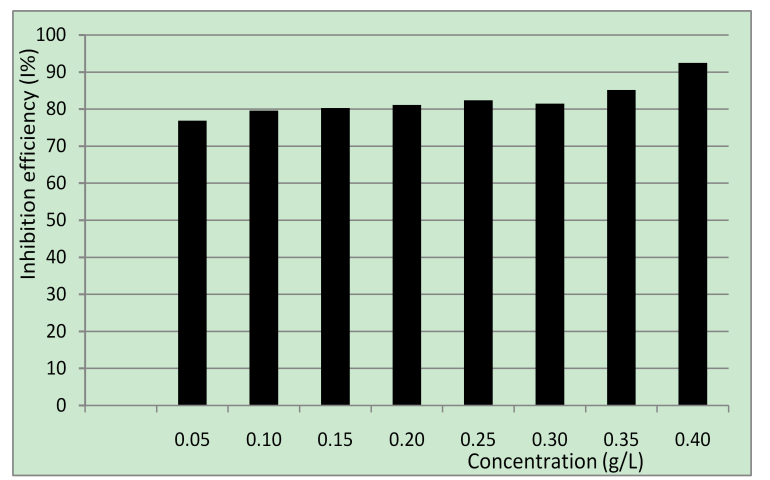

Figure 4. Variation of inhibition efficiency with concentration of Newbouldia leavis leaf extract for aluminium in $0.5 \mathrm{M} \mathrm{H}_{2} \mathrm{SO}_{4}$

The result that the inhibition efficiency of Newbouldia leavis leaf extract increases with increase in inhibitor concentration suggests that some of the molecules of the inhibitor are adsorbed on the metal surface thereby protecting the "covered" surface from further corrodent attack. Increasing the inhibitor concentration increases the degree of surface coverage, $\theta$, of the metal surface defined as:

$$
\theta=1-\frac{\rho_{\text {in }}}{\rho_{\text {blank }}}
$$

The Newbouldia leavis leaf extract consists of a mixture of complex organic components including flavonoids, several phenolic compounds ( $\beta$-carotene - linoleic acids) and some other organic compounds. The plant extract also contains some nutritional minerals including potassium, magnesium, copper and zinc[35-38].

It is interesting to note that a number of the above named organic compounds exhibit antioxidant activity. For example, nasunin (a flavonoid), $\beta$-carotene - linoleic acids (phenolic compounds) are antioxidants. Results of earlier studies suggest that tannins and some antioxidant compounds in plant extracts contribute to inhibition of steel corrosion in some acidic medium[15,19,39]. In fact, plant/leaf extracts which have proven corrosion inhibiting abilities in corrosive media are known to contain one or more more of the following organic substances, namely tannins, triterpenoids, flavonoids, amino acids, alkaloids, saponins, phenols, glycosides, essential oils, carotenoids, $\beta$-carotene, ascorbic acid, crude proteins among others $[4,5,10,12,19]$. Some research workers[40-42] have demonstrated that amino acids are indeed effective corrosion inhibitors. It is therefore reasonable to expect that the presence of amino acids, antioxidant organic compounds(nasunin - a flavonoid, caffeic and chlorogenic acids - phenolic compounds), crude proteins or indeed any other of the complex organic substances in the Newbouldia leavis leaf extract could in combination with the other constituents be responsible for the inhibition of aluminium corrosion in $0.5 \mathrm{M} \mathrm{H}_{2} \mathrm{SO}_{4}$. Moreover, the presence of some metallic ions particularly $\mathrm{Mg} 2+$ may enhance the corrosion inhibiting action of the extract. This is because it has been observed that some inorganic ions particularly $\mathrm{Ca}^{2+}$, $\mathrm{Mg}^{2+}$ and $\mathrm{Zn}^{2+}$ ions synergistically increase the inhibition efficiency of organic substances[4,43,44]. Nevertheless, it is not possible at this point to identify the particular constituent or group of constituents of the plant extract that are adsorbed onto the metal surface. In any case, the adsorbate molecules on the metal surface constitute a barrier to charge and mass transfer between the metal and the corrodent, thereby protecting the metal surface from corrodent attack. The larger the degree of surface coverage resulting from enhanced adsorption of molecules of the plant extract, the greater the protection to corrosion offered by the inhibitor[10].

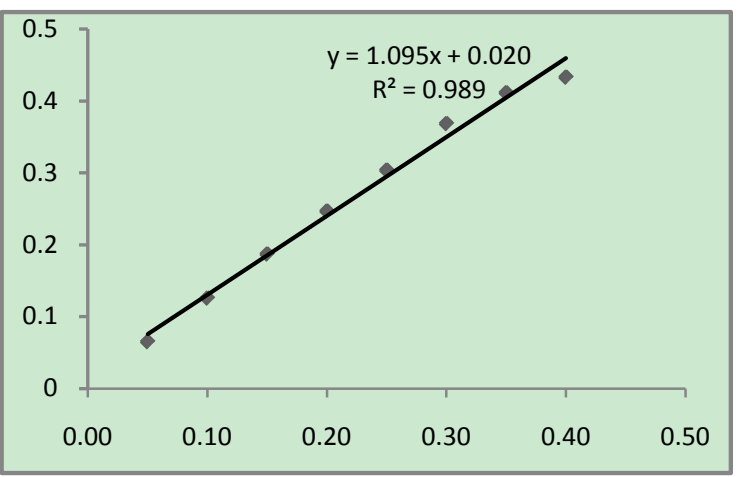

Figure 5. Langmuir adsorption isotherm for inhibition of aluminium in $0.5 \mathrm{M} \mathrm{H}_{2} \mathrm{SO}_{4}$ by Newbouldia leavis leaf extract 
Table 1. Values of Langmuir isotherm parameters for aluminium alloy

\begin{tabular}{|c|c|c|c|c|c|}
\hline $\begin{array}{c}\text { Plant } \\
\text { extract }\end{array}$ & Intercept & Slope & $\begin{array}{c}\mathrm{K}(\mathrm{x} \\
10-4)\end{array}$ & $\mathrm{R} 2$ & $\Delta \mathrm{Go}(\mathrm{kJmol}-1)$ \\
\hline $\begin{array}{c}\mathrm{NL} \text { in } \\
0.5 \mathrm{M}\end{array}$ & 1.09 & 0.02 & 8.3 & 0.989 & -7.76 \\
$\mathrm{H} 2 \mathrm{SO} 4$ & & & & & \\
\hline
\end{tabular}

Table 2. Calculated values of inhibition efficiency (I\%), apparent activation energy (Ea) and heat of adsorption (Qads) of Newbouldia leavis extract on AA8011 aluminium alloy in $0.5 \mathrm{M} \mathrm{H}_{2} \mathrm{SO}_{4}$ at different temperatures

\begin{tabular}{|c|c|c|c|c|}
\hline \multirow{2}{*}{$\begin{array}{c}\text { Extract con- } \\
\text { centration }(\mathrm{g} / \mathrm{L})\end{array}$} & \multicolumn{2}{|c|}{$\begin{array}{c}\text { Inhibition effi- } \\
\text { ciency }(\mathrm{I} \%)\end{array}$} & \multirow{2}{*}{$\mathrm{E}_{\mathrm{a}}\left(\mathrm{kJmol}^{-1}\right)$} & \multirow{2}{*}{$\mathrm{Q}_{\text {ads }}\left(\mathrm{kJmol}^{-1}\right)$} \\
\cline { 2 - 3 } & $30^{\circ} \mathrm{C}$ & $60^{\circ} \mathrm{C}$ & & \\
\hline Blank & & & & \\
\hline 0.10 & 76.86 & 50.20 & 62.85 & -559.89 \\
\hline 0.15 & 79.62 & 58.65 & 54.04 & -506.36 \\
\hline 0.20 & 80.29 & 61.69 & 41.52 & -463.76 \\
\hline 0.25 & 81.41 & 65.35 & 51.76 & -421.06 \\
\hline 0.30 & 82.41 & 69.72 & 38.16 & -355.01 \\
\hline 0.35 & 85.16 & 71.14 & 29.26 & -422.33 \\
\hline 0.40 & 92.47 & 76.25 & 31.41 & -670.54 \\
\hline
\end{tabular}

Table 3. Major constituents of Newbouldia leavis $[45,46]$

\begin{tabular}{|c|c|}
\hline Plant & Major constituents \\
\hline $\begin{array}{c}\text { Newbouldia } \\
\text { leavis }\end{array}$ & $\begin{array}{c}\text { flavonoids, tannins, terpenes, steroidal and } \\
\text { cardiac glycosides }\end{array}$ \\
\hline
\end{tabular}

\subsection{Adsorption considerations and Adsorption Isotherms}

In the situation where it is suspected that the inhibition of metal corrosion occurred as a result of the adsorption of molecules of plant extracts onto the metal surface, it is instructive to investigate the possible adsorption mode by testing the experimental data obtained with several adsorption isotherms. Such an exercise will greatly elucidate one's understanding of the corrosion inhibition mechanism. The generalized expression for several adsorption isotherms usually tested is of the form[20,34,47].

$$
f(\theta, x) \exp (-\alpha \theta)=k C
$$

where $\mathrm{f}(\theta, \mathrm{x})$ is the configuration factor whose functional form depends on the physical model adopted and assumptions made in deriving the isotherm, $\theta$ is the degree of surface coverage, $\mathrm{x}$ is known as the size ratio which gives the number of water molecule replaced by the inhibitor molecule, $\alpha$ is a molecular interaction parameter whose value depends on the type of molecular interactions in the adsorption layer and the degree of homogeneity of the surface, $\mathrm{C}$ is the inhibitor concentration while $\mathrm{k}$ is the adsorption equilibrium constant which is temperature dependent according to the relation[17,32,34,47,48].

$$
k=\frac{1}{55.5} \exp \left(-\frac{\Delta G_{a d s}}{R T}\right)
$$

where $\Delta G_{a d s}$ is the standard free energy of adsorption, $\mathrm{R}$, is the molar gas constant and $\mathrm{T}$ is absolute temperature. Several adsorption isotherms were tested for fit with the experimental data. These include the Langmuir, Frumkin, Temkin, Freundlich and the Flory-Huggins isotherms. Incidentally, the Langmuir isotherm gave the best fit with the experimental data. The Langmuir isotherm equation is of the form[10,17,20,39,47]:

$$
C / \theta=1 / k+C
$$

From a plot of $\frac{C}{\theta}$ against $C$, a straight line graph was obtained with a slope of 0.02 and an intercept of 1.09 on $\frac{C}{\theta}$ axis. The coefficient of correlation, $R^{2}$, gave the degree of fit between the experimental data and the isotherm equation. The value obtained was found to be 0.989 , which indicates a very good fit between the Langmuir isotherm and the experimental data. Figure 5 shows the Langmuir isotherm plot for the inhibition of the corrosion of aluminium in $0.5 \mathrm{M}$ $\mathrm{H}_{2} \mathrm{SO} 4$ by Newbouldia leavis leaf extract. Using the value of intercept obtained from the graph and equations 4 and 5 a value of $-7.76 \mathrm{kJmol}^{-1}$ was obtained for $\mathrm{G}_{\text {ads. }}^{\mathrm{o}}$. The very good fit of the experimental data with the Langmuir adsorption isotherm suggests that the Langmuir adsorption model is applicable in the corrosion inhibition mechanism. In the derivation of the Langmuir isotherm, it was assumed that the adsorption sites on the metal surface are uniformly distributed and energetically identical and that the maximum number of adsorbed molecules per site is one, implying a case of monolayer adsorption. Additionally, it was assumed that adsorbate molecules do not interact with one another.

The negative value of $G^{0}$ ads, the Gibb's free energy of adsorption, obtained means that the adsorption process was spontaneous.

The value of $\mathrm{G}_{\text {ads }}^{\mathrm{o}}$ obtained in this study is low enough for one to attribute the adsorption process as due to an electrostatic interaction between the atoms/ions on the metal surface and the adsorbate molecules[49], a mechanism which is consistent with physical adsorption (physiosorption). The obtained value of the slope of the Langmuir isotherm plot of 1.09 which is about unity (the expected value for ideal Langmuir isotherm model) authenticates the physiosorption. The value of the standard free energy of adsorption is still within the energy range characterising the physiosorption model of adsorption. It has been pointed out $[22,24,47,50]$ that generally, values of $\mathrm{G}_{\text {ads }}^{\mathrm{o}}$ up to -20 kJmol-1 are consistent with physical adsorption. The interactions involved in this mechanism are more or less weak electrostatic interactions between metal atoms and adsorbate species. In fact, the adsorption energies involved have the same range of energy values as the van der Waals bond energies[49]. However, values of $\mathrm{G}_{\text {ads }}^{\mathrm{o}}$ which are more negative than - $40 \mathrm{kJmol}^{-1}$ are associated with chemical adsorption, also called chemisorption. The mechanism involves charge sharing or charge transfer between the atoms of the metal and the adsorbate molecules. The associated bonds are strong and the corresponding bond energies could be as large as those characteristics of primary bonds in solids[49].

\subsection{Effect of Temperature}

The apparent activation energies $\left(E_{a}\right)$ for the corrosion process in absence and presence of inhibitor were evaluated from Arrhenius equation.

$$
\log \frac{\rho_{2}}{\rho_{1}}=\frac{E_{\mathrm{a}}}{2.303 \mathrm{R}}\left(\frac{1}{\mathrm{~T}_{1}}-\frac{1}{\mathrm{~T}_{2}}\right)
$$


On the other hand, estimates of the heats of adsorption $\left(Q_{\text {ads }}\right)$ were obtained from the trend of surface coverage with temperature as follows[51]:

$$
Q_{a d s}=2.303 \mathrm{R}\left[\log \left(\frac{\theta_{2}}{1-\theta_{2}}\right)-\log \left(\frac{\theta_{1}}{1-\theta_{1}}\right)\right] \times \frac{\mathrm{T}_{1} \mathrm{~T}_{2}}{\mathrm{~T}_{2}-\mathrm{T}_{1}}
$$

$\rho_{1}$ and $\rho_{2}$ are the corrosion rates in temperatures $T_{1}$ and $T_{2}$, respectively while $\theta_{1}$ and $\theta_{2}$ are the degrees of surface coverage at temperature $T_{1}$ and $T_{2}$ and $R$ is the gas constant.

\section{Conclusions}

It has been shown in this study that the addition of Newbouldia leavis leaf extract to $\mathrm{H}_{2} \mathrm{SO}_{4}$ reduces the corrosion rate of aluminium in the acid. The inhibition efficiency of the plant extracts increases with increase in concentration although it decreases with rise in temperature. The experimental data obtained are best described by the Langmuir adsorption isotherm, signifying the formation of a single layer of inhibitor molecules onto aluminium alloy surface. Moreover, value of the Gibb's free energy of adsorption obtained suggests that the spontaneous physical adsorption of the plant extract molecules is the most likely inhibitory mechanism responsible for the reduction of the corrosion rate of the aluminium in $0.5 \mathrm{M} \mathrm{H}_{2} \mathrm{SO}_{4}$ containing Newbouldia leavis leaf extract.

\section{REFERENCES}

[1] Caporali S, Fossati A, Lavacchi A, Perissi I, Tolstogouzov A, Bardi U (2008). Aluminium electroplated from ionic liquids as protective coating against steel corrosion. Corros. Sci., 50: 534-539

[2] Fang H, Chen K, Zhang Z, Zhu C (2008). Effect of Yb addition on microstructure and properties of 7A60 aluminium alloy. Trans. Nonferrous Met. Soc. China. 18: 28-32

[3] Rosaliza R, Wan Nik WB, Senin HB (2008). The effect of inhibitor on the corrosion of aluminium alloys in acidic solutions. Mater. Chem. Phys., 107: 281-288

[4] Oguzie EE, Onuoha GN, Ejike EN (2007). Effect of Gongronema latifolium extract on aluminium corrosion in acidic and alkaline media. Pigment Resin Technol., 36(1): 44-49

[5] Nnanna LA, Onwuagba BN, Mejeha IM, Okeoma KB (2010). Inhibition effects of some plant extracts on the acid corrosion of aluminium alloy. Afr. J. Pure Appl. Chem., 4(1): 11-16

[6] Gomma G. (1998). Corrosion of low carbon steel in sulphuric acid solution in the presence of pyrazole-halide mixture. Mater. Chem. Phys., 55(3): 241-247

[7] Callister WD (2003). Materials Science and Engineering: An Introduction, John Wiley and Sons Inc. New York, p. 579

[8] Obot I, N., Obi-Egbedi (2009). Adsorption characteristics and Corrosion Inhibitive properties of Clotrimazole for Aluminium Corrosion in Hydrochloric Acid. Int. J. Electrochem. Sci., 4(6):1277-1288
[9] Zhang H, Zuo Y (2008). The improvement of corrosion resistance of $\mathrm{Ce}$ conversion films on aluminium alloy phosphate post - treatment. Appl. Surface Science, www.scie ncedirect.com

[10] Oguzie EE (2008a). Corrosion inhibitive effect and adsorption behaviour of Hibiscus sabdariffa on mild steel in acidic media. Portugaliae Electrochemica Acta., 26: 303-314

[11] Ebenso EE (2004). Effect of methyl red and halide ions on the corrosion inhibition of aluminium in $\mathrm{H}_{2} \mathrm{SO}_{4}$ : Part 2. Bull. Electrochemica 20: 551-559

[12] Mejeha I. M., Uroh A. A., Okeoma K. B., Alozie G. A., (2010). The inhibitive effect of Solanum melongena L. Leaf extract on the corrosion of aluminium in tetraoxosulphate (VI) acid. Afr. J. Pure Appl. Chem., 4(8): 158-165

[13] Ekpe UJ, Ebenso EE, Ibok UJ (1994). Inhibitory actions of Azadirachta indica leaf extract on the corrosion of mild steel in H2SO4. J. W. Afr. Sci. Assoc., 39: 13-30

[14] Ebenso EE, Ibok UJ (1998). Studies on the inhibition of mild steel corrosion by some plant extracts in acidic medium. Discov. Innov., 10: 52-59

[15] Martinez S, Stern I (2001). Inhibitory mechanism of low carbon steel corrosion by minosa tannin in sulphuric acid solutions. J. Appl. Electrochem., 31(9): 973-978

[16] Popova A., Christov M., Raicheva S., Sokolova E. (2004). Adsorption and Inhibitive properties of Benzimidazole Derivatives in Acid Mild Steel Corrosion. Corros. Sci. 46:1333-1350

[17] Emregul KC, Hayvali M (2004). Studies on the effect of vanillin and protocatechualdehyde on the corrosion of steel in hydrochloric acid. Mater. Chem. Phys., 83: 209-216

[18] Oguzie EE, Ebenso EE (2006). Studies on inhibitive effect of congo red dye - halide mixtures. Pigment Resin Technol., 35(1): $30-35$

[19] Oguzie EE (2008b). Evaluation of some inhibitive effect of some plant extracts on the acid corrosion of mild steel. Corros. Sci., 50: 2993- 2998

[20] Ebenso EE, Eddy NO, Odiongenyi AO (2009). Corrosion inhibition and adsorption properties of methacarbanol on mild steel in acidic medium. Portugaliae Electrochemica Acta., 27(1): 13-22

[21] El-Etre AY (2003). Inhibiton of aluminium corrosion using opuntia extract. Corro. Sci. 45: 2485-2493

[22] Ebenso EE (2003). Synergistic effect of halide ions in the corrosion inhibition of aluminium in $\mathrm{H}_{2} \mathrm{SO}_{4}$ using 2- acetylphenophiazine. Mater. Chem. Phys., 78: 58-70

[23] Ebenso EE, Ekpe UJ, Umoren S, Ekerete J, Abiola OK, Oforka NC (2004a). Synergistic effect of halide ions on the corrosion inhibition of aluminium in acidic medium by some polymers. J. Corros. Sci. Technol., 1(1): 22-26

[24] Ebenso EE, Ekpe UJ, Umoren S, Ekerete J, Abiola OK, Oforka NC, Martinez S (2004b). Corrosion inhibition studies of some plant extracts on aluminium in acidic medium. J. Corros. Sci. Techol., 1(1): 96-101

[25] Oguzie EE, Okolue BN, Ebenso EE, Onuoha GN, Onuchukwu AI (2004a) Evaluation of the inhibitory effect of 
methylene blue dye on the corrosion of aluminium in hydrochloric acid. Mater. Chem. Phys., 87(2/3): 394-401

[26] Oguzie EE, Okolue BN, Ogukwe CE, Onuchukwu AI, Unaegbu C (2004b). Studies on the inhibitive action of methylene blue dye on aluminium corrosion in $\mathrm{KOH}$ solution. J. Corros. Sci. Technol., 1(1): 88-91

[27] Ebenso EE, Ekpe UJ, Umoren S, Ekerete J, Abiola OK, Oforka NC (2004a). Synergistic effect of halide ions on the corrosion inhibition of aluminium in acidic medium by some polymers. J. Corros. Sci. Technol., 1(1): 22-26

[28] Umoren SA, Obot IB, Ebenso EE, Okafor PC, Ogbobe O, Oguzie EE (2006a). Gum Arabic as a potential corrosion inhibitor for aluminium in alkaline medium and its adsorption characteristics. Anti-corrosion Methods and Materials, 53: 277-282

[29] Umoren SA, Ogbobe O, Ebenso EE, Ekpe UJ (2006b). Effect of halides ions in the corrosion inhibition of mild steel in acidic medium using polyvinyl alcohol. Pigment Resin Technol., 35: 284-292

[30] Umoren SA, Ebenso EE, Okafor PC, Ekpe UJ, Ogbobe O (2007). Effect of halide ions on corrosion inhibition of aluminium in alkaline medium using polyvinyl alcohol. J. Appl. Polymer Sci., 103: 2810-2816. World Healthiest Foods (WHFoods). Weekly Newsletter on eggplant

[31] Nnanna L. A., Anozie I. U., Avoaja A. G. I., Akoma C. S., Eti E. P., (2011). Comparative study of corrosion inhibition of aluminium alloy of type AA3003 in acidic and alkaline medium bu Euphorbia hirta extract. Afr. J. Pure Appl. Chem., 5(8): $265-271$

[32] Martinez S (2002). Inhibitory mechanism of mimosa tannin using molecular modelling and substitutional adsorption isotherms. Mater. Chem. Phys., 77: 97-102

[33] Abiola O., Okafor N., Ebenso E., Nwinuka N. (2007). Eco-Friendly Corrosion inhibitors: Inhibitive actions of Delonis regia extract for the Corrosion of Aluminium in Acidic medium. Anti-Corros. Methods Mater., 54: 219-224

[34] Ameer MA, Khamis E, Al-Sanani G (2000). Adsorption studies of the effect of thiosemicarbazides on the corrosion of steel in phosphoric acid. Adsorpt. Sci. Tech., 18: 177-194

[35] Akunyili, D.N. (2000). Anticonvulsant Activity of the Ethanolic extract of Newbouldia leavis. 2nd NAAP Scientific conference. $155-8$

[36] Sudheesh S, Presannakuma G, Vijayakumar S, Vijayalokshmi NR (1997). Hypolipidemic effect of flavonoids from Solanum melongena L. J. Plant Foods Hum. Nutri., 51(4): 321-330

[37] Sudheesh S, Sandhya C, Koshy AS, Vijayalakshmi NR (1999). Antioxidant activity of flavonoids from Solanum melongena L. Phytother. Res., 13(5): 393-396

[38] Flick GJ, Org RL, St Angelo AJ (1977). Comparison of the nutrient composition and enzyme activity in purple, green and white eggplants. J. Agric. Food Chem., 25(1): 117-120

[39] Eddy NO, Ebenso EE (2008). Adsorption and inhibitive properties of ethanol extract of Musa sapientum peels as a green corrosion inhibitor for mild steel in $\mathrm{H} 2 \mathrm{SO} 4$. Afr. J. Pure Appl. Chem., 2(6): 46 - 54

[40] Al-Mayouf AM (1996). Amino acids as corrosion inhibitors for aluminium in acid chloride solutions. Corros. Prev. Ctrl., 6(1): $68-74$

[41] Badawy WA, Ismail KM, Fathi AM (2006). Corrosion control of $\mathrm{Cu}-\mathrm{Ni}$ alloys in neutral chloride solutions by amino acids. Electrochemica Acta., 51(20): 4182-4189

[42] Helal NH, El-Rabiee MM, Abd El-Hafez GhM, Badawy WA (2008). Environmentally safe corrosion inhibition of $\mathrm{Pb}$ in aqueous solutions. J. Alloys Compounds. 456(1-2): 272-278

[43] Karman FH, Cserny J, Kalman E (1993). Surface study of corrosion inhibitors. Progress Understanding Prevention Corrosion, 2: 920-922

[44] Rajendran S, Maria Joany R, Apparao BV, Palaniswamy N (2000). Synergistic effect of calcium gluconate and $\mathrm{Zn} 2+$ on the inhibition of corrosion of mild steel in neutral environment. Transactions of the SAEST 35(3/4): 113-117

[45] Sofowora, A. (1993). Screening Plants for Bioactive Agents. In: Medicinal plants and Traditional Medicinal in Africa. 2nd Ed. Spectrum Books Ltd, Sunshine House, Ibadan, Nigeria, pp. $134-156$

[46] Trease, G.E. and Evans, W.C. (2002). Pharmacognosy. 15th Ed. Saunders Publishers, London. pp. 42 - 44, 221 - 229, 246 249, 304 - 306, 331 - 332, 391 - 393

[47] Iannuzzi M, Frankel GS (2007). Mechanisms of corrosion inhibition of AA2024-T3 by vanadates. Corros. Sci., 49: 2371-2391

[48] Popova A, Sokolova E, Raicheva S, Christov M (2003). AC and DC study of temperature effect on mild steel corrosion in acidic media in the presence of benzimidazole derivatives. Corros. Sci., 45(1): 33 - 58

[49] Raghavan V (1989). Materials Science and Engineering: A First Course. Third Edition. Prentice - Hall of India Private Limited, New Delhi

[50] Bilgic S, Sahin M (2001). The corrosion inhibition of austenistic chromium- nickel steel in $\mathrm{H} 2 \mathrm{SO} 4$ by $2-$ butyn-1-ol. Mater. Chem. Phys., 70: 290-295

[51] Bhajiwala, H M. and Vashi, R T., 2002, Ethanolamine, diethanolamine and triethanolamine as corrosion inhibitors for zinc in binary acid mixture $(\mathrm{HNO} 3+\mathrm{H} 3 \mathrm{PO} 4)$, Bulletin of Electrochemistry, 17(10), $441-448$. Saleh, R. M. and Shams El Din, A. M., 1972. Efficiency of organic acids and their anions in retarding the dissolution of aluminium., Corrosion Science, 12(9), 689-697 